\title{
Pyrolysis Behaviors, Kinetics, and Byproducts of Enzymatic Hydrolysis Residues for Lignocellulosic Biorefining
}

\author{
Rongwen Zhao, ${ }^{\mathrm{b}}$ Zhongyang Liu, ${ }^{\mathrm{b}}$ Tongjun Liu, ${ }^{\mathrm{a}, \mathrm{b}, *}$ and Liping Tan ${ }^{\mathrm{a}, \mathrm{b}, *}$ \\ Enzymatic hydrolysis residues (EHR) are the solid wastes from enzymatic \\ hydrolysis and/or fermentation of the cellulosic bioethanol industry. These \\ byproducts have not been effectively used. Thermogravimetric analysis \\ with infrared spectroscopy (TG-IR) and pyrolysis-gas chromatography/ \\ mass spectrometry (Py-GC/MS) were used to quantify the pyrolytic \\ bioenergy potential of EHR with alkaline hydrogen peroxide (AHP) and \\ bisulfite (BSF) pretreatment through assessing their pyrolysis behaviors, \\ kinetics, and byproducts. The TG-IR analysis showed that the EHR \\ pyrolysis temperature range was $180^{\circ} \mathrm{C}$ to $620^{\circ} \mathrm{C}$ and consisted of three \\ consecutive stages: dehydration, rapid pyrolysis, and carbonization. The \\ main volatile products evolved from the EHR pyrolysis were $\mathrm{CO}, \mathrm{CO}_{2}$, \\ $\mathrm{H}_{2} \mathrm{O}$, and $\mathrm{CH}_{4}$. Fast pyrolysis results from $\mathrm{Py}-\mathrm{GC} / \mathrm{MS}$ indicated that the \\ main pyrolytic byproducts of EHR were phenols $(30.68 \%)$, furans \\ (14.27\%), and acids (8.52\%) for AHP-EHR; and phenols (26.75\%), furans \\ (15.54\%), and acids (10.33\%) for BSF-EHR. The results provide insights \\ for expanding the potential of bioenergy and increasing the value-added \\ byproducts based on the biomass part of EHR.
}

Keywords: Pyrolysis behavior; Enzymatic hydrolysis residues; Corn stalk; Alkaline hydrogen peroxide pretreatment; Bisulfite pretreatment

Contact information: a: State Key Laboratory of Biobased Material and Green Papermaking, Qilu University of Technology, Shandong Academy of Sciences, Jinan, 250353, China; $b$ : Shandong Provincial Key Laboratory of Microbial Engineering, Department of Bioengineering, Qilu University of Technology, Shandong Academy of Sciences, Jinan, 250353, China;

*Corresponding authors: tanliping163@163.com; liutongjun@outlook.com

\section{INTRODUCTION}

Cellulosic bioethanol production from lignocellulosic feedstock has been advancing rapidly in recent years as a strategy to remedy the energy crisis and foster sustainable development (Soccol et al. 2019). Enzymatic hydrolysis residues (EHR), the byproducts from enzymatic hydrolysis and/or fermentation of the cellulosic bioethanol industry, constitute increasing solid wastes and are conventionally discarded or even burned (Tripathi et al. 2016; Zhang et al. 2018). As energy is constantly being consumed worldwide, it is important to recover as much heat or energy as possible from the waste. The EHR are rich in thermally decomposable components, such as lignin and carbohydrate polymers, which have great potential in the production of biogas, biofuel, and chemical products (Kan et al. 2016; Cai et al. 2018). Making full use of these solid wastes not only can reduce environmental pollution but also reduce the cost of bioethanol, to realize the biorefinery of lignocellulosic feedstock, which has been paid increasing attention by researchers all over the world. Pyrolysis, which has the unique advantages of being environmentally and economically friendly, is the thermal process to convert biomass to 
high-quality biofuels and chemicals such as biochar, biogas, or, bio-oil (Dhyani and Bhaskar 2018; Barr et al. 2019).

Thermogravimetric analysis combined with infrared spectroscopy (TG-IR) and pyrolysis-gas chromatography/mass spectrometry (Py-GC/MS) is the most common way to estimate pyrolysis behavior and byproducts of biomass, polymers, and even waste (Li et al. 2017a; Chen et al. 2019; Li et al. 2020). The TG-IR method allows facile evaluation of pyrolysis by determining the decomposition characteristics and products as well as the measurement of multiple gas products in a complex matrix simultaneously and in real-time (Ferreira et al. 2019). The TG-IR analysis targets the thermal degradation of samples in an inert atmosphere, and it sensitively records the weight loss of the matrix at a constant heating rate (Wu et al. 2018). Complex chemical reactions are not considered during the thermal decomposition, and kinetic parameters can be readily calculated by thermogravimetric analysis ( $\mathrm{Gu}$ et al. 2014). In recent years, many researchers have adopted TG-IR to analyze the pyrolysis of biomass and examine its kinetics. Li et al. (2014) used TG-IR to study the pyrolysis of sodium lignosulfonate, to analyze the evolution of typical gaseous products (water, $\mathrm{CO}_{2}$, and $\mathrm{CO}$ ), and to correlate the chemical structure with the pyrolysis behavior. Wang et al. (2014) used TG-IR to study the pyrolysis of pyrolytic lignin and milled wood lignin and concluded that the source of the lignin plays an important role in pyrolysis products. The Py-GC/MS can be applied semi-quantitatively to detect the byproducts of the fast biomass pyrolysis. The pyrolytic performances, kinetic, thermodynamic behaviors, and byproducts of water hyacinth roots, stems, and leaves are more accurately determined by TG-IR and Py-GC/MS analyses (Huang et al. 2020).

As a type of solid waste from cellulosic bioethanol production, EHR have complex structure with a heterogeneous composition that is dependent on the pretreatment process. Pretreatment is necessary for the effective conversion of lignocellulosic biomass into bioethanol due to "biomass recalcitrance". Pretreatment with alkali (Chen et al. 2018), acid (Li et al. 2019), ammonia fibre expansion (Jin et al. 2016), or ionic liquid pretreatment (Papa et al. 2017) increases the enzymatic digestibility of lignocellulosic biomass and forms different kinds of EHR. Alkaline hydrogen peroxide (AHP) and bisulfite (BSF) pretreatment are well-established pretreatment methods that improve the enzymatic hydrolysis of lignocellulosic biomass for bioethanol production (Tan et al. 2016; Ho et al. 2019). The AHP pretreatment is carried out under mild conditions and destroys the lignin structure by saponification; this is done to dissolve and swell the lignin and thus reduce its degree of polymerization (Deng et al. 2019). Moreover, the AHP process does not tend to produce inhibitors that are detrimental to enzyme hydrolysis, and the peroxide oxidant added under alkaline condition can act as a mild solubilizer to partially promote the dissolution of hemicellulose (Liu et al. 2019; Zhang et al. 2019). In the BSF pretreatment, the solution of acid bisulfite contains $\mathrm{H}^{+}, \mathrm{HSO}_{3}{ }^{-}$, and $\mathrm{SO}_{3}{ }^{2-}$, which can attack and dissolve lignin via sulfonation (Tan et al. 2015). Hemicellulose can be also broken down to monosaccharides in the spent liquid under acidic condition, to thus expose as much cellulose as possible (Luo et al. 2010). Studies have shown that the sulfonated lignin generated from the BSF process can serve as an amphiphilic polymer to improve the enzymatic hydrolysis efficiency of lignocellulosic biomass (Wang et al. 2013; Chandra et al. 2015).

To date, there has been little research on the pyrolysis of EHR with different pretreatment. To deeply understand the pyrolysis behaviors, kinetics, and byproducts of EHR with AHP and BSF pretreatment, pyrolysis experiments were performed using the combination of TG-IR and Py-GC/MS analyses. The results and information obtained from 
this pyrolysis process can provide a reference for biorefining and mechanistic studies of EHR pyrolysis with different kinds of the pretreatment process.

\section{EXPERIMENTAL}

\section{Materials}

The corn stalk was harvested from Weifang (Shandong Province, China). It was airdried until constant moisture content was achieved (approximately 10\%). The corn stalk was milled and then stored in sealed bags at room temperature.

The commercial Cellic ${ }^{\circledR}$ CTec2 was bought from Novozymes (Copenhagen, Denmark). The filter paper activity was determined to be 90 FPU/mL. Sulfuric acid, sodium bisulfite, hydrogen peroxide, and sodium hydroxide were of analytical grade (Aladdin, Shanghai, China). D-(+)glucose and D-(+)xylose were of chromatographic grade (Aladdin, Shanghai, China).

\section{Methods}

Alkaline hydrogen peroxide pretreatment

Alkaline hydrogen peroxide (AHP) pretreatment, which was performed previously (Liu et al. 2014), was prepared by soaking corn stalk in alkaline hydrogen peroxide solution at $30{ }^{\circ} \mathrm{C}$ for $24 \mathrm{~h}$. The corn stalk loading in the AHP pretreatment was $10 \%$, and the $\mathrm{H}_{2} \mathrm{O}_{2}$ dosage (based on the weight of dry corn stalk, w/w) was $10 \%$. The $\mathrm{pH}$ value was periodically adjusted to 11.5 using $5 \mathrm{M} \mathrm{NaOH}$. After pretreatment, the insoluble solids after AHP pretreatment (AHP-S) were collected and then stored in plastic bags for further analysis and enzymatic hydrolysis.

\section{Bisulfite pretreatment}

The bisulfite (BSF) pretreatment was described in the previous paper (Tan et al. 2013). In the BSF process, the corn stalk reacted with a solution of $\mathrm{NaHSO}_{3}$ and $\mathrm{H}_{2} \mathrm{SO}_{4}$ at $170{ }^{\circ} \mathrm{C}$ for $30 \mathrm{~min}$. The chemical dosages (based on the weight of dry corn stalk, w/w) were $7 \% \mathrm{NaHSO}_{3}$ and $1 \% \mathrm{H}_{2} \mathrm{SO}_{4}$. The ratio of corn stalk to liquor was $1: 4$. Then, the insoluble solids after BSF pretreatment (BSF-S) were collected and then stored for further experiments.

\section{Formation of enzymatic hydrolysis residues (EHR)}

The AHP-S and BSF-S were hydrolyzed in the flasks by Cellic ${ }^{\circledR}$ CTec 2 to evaluate their enzymatic digestibility. The enzymatic hydrolysis conditions are as follows: $\mathrm{pH}$ level of 4.8 ( $0.05 \mathrm{M}$ sodium acetate buffer), $2 \%$ solid concentration (on dry weight), $50{ }^{\circ} \mathrm{C}, 200$ rpm in a shaker, and cellulase dosage of $10 \mathrm{FPU} / \mathrm{g}$ dry sample. Hydrolysates were centrifuged and used for glucose content analysis. Conversion of cellulose to glucose was calculated as the previous study (Tan et al. 2013). Then, the EHR were collected and vacuum-dried at $40{ }^{\circ} \mathrm{C}$ for $48 \mathrm{~h}$, which was named as AHP-EHR (EHR after AHP pretreatment) and BSF-EHR (EHR after BSF pretreatment) for further analysis.

\section{Thermogravimetry-infrared (TG-IR) analysis}

The AHP-EHR and BSF-EHR were put into the ceramic crucibles in the furnace of the thermogravimetric analyzer (PerkinElmer TGA 4000, Walsham, Massachusetts, USA) connected to an IR spectrometer (PerkinElmer Spectrum Two, Walsham, Massachusetts, 
USA). The system was first purged with high-purity $\mathrm{N}_{2}$. The furnace temperature was then increased from $30{ }^{\circ} \mathrm{C}$ to $800{ }^{\circ} \mathrm{C}$ at the heating rate of $20^{\circ} \mathrm{C} / \mathrm{min}$ under the protection of 20 $\mathrm{mL} / \mathrm{min} \mathrm{N}_{2}$ flow to obtain the thermogravimetric (TG) and derivative thermogravimetric (DTG) curves. Meanwhile, the gaseous decomposition products were introduced into the gas reservoir of the IR spectrometer via a transfer line for the real-time composition analysis. The IR spectra were recorded in the range of 400 to $4000 \mathrm{~cm}^{-1}$ at the resolution of $4 \mathrm{~cm}^{-1}$.

Kinetic models for EHR pyrolysis

All studies on the kinetics of thermal analysis assume that the Arrhenius equation can represent the relationship between the chemical reaction rate and temperature. Based on the analysis of Van't Hoff, Arrhenius in 1889 introduced the relationship between the rate constant $k$ and the temperature $T$ of a given chemical reaction (Huang et al. 2011):

$$
k=A \exp \left(-\frac{E}{R T}\right)
$$

A solid phase reaction may be represented by the following equation,

$$
A(\mathrm{~s}) \rightarrow B(\mathrm{~s})+C(\mathrm{~g})
$$

where $A$ is the reactant, $B$ is the solid phase residue after pyrolysis, and $C$ is the products in the gaseous phase. The rate of reaction can then be defined as,

$$
\frac{d \alpha}{d \mathrm{t}}=k \mathrm{f}(\alpha)
$$

where $\alpha$ is the conversion of the reactant that can be represented as follows,

$$
\alpha=\frac{W_{0}-W_{t}}{W_{0}-W_{f}}
$$

in which $W_{0}, W_{\mathrm{t}}$, and $W_{\mathrm{f}}$ are the reactant mass at the start of the reaction, at time $t$, and the end of the reaction, respectively. The kinetic equation of the solid phase under isothermal conditions can be derived from the Arrhenius equation:

$$
\frac{d \alpha}{d t}=A \exp \left(-\frac{E}{R T}\right) \mathrm{f}(\alpha)
$$

The following applies when the reaction is not carried out at constant temperature,

$$
T=T_{0}+\beta t
$$

that is:

$$
\beta=\frac{d T}{d t}
$$

Therefore, the kinetic equation of the solid phase at a variable temperature is as follows,

$$
\frac{d \alpha}{d T}=\frac{A}{\beta} \exp \left(-\frac{E}{R T}\right) \mathrm{f}(\alpha)
$$

where $T(\mathrm{~K})$ is the temperature of the sample, $A\left(\mathrm{~min}^{-1}\right)$ is the frequency coefficient, $E$ $(\mathrm{kJ} / \mathrm{mol})$ is the activation energy of the pyrolysis reaction, $\beta\left(\mathrm{min}^{-1}\right)$ is the rate of heating, 
$R=8.314 \times 10^{-3} \mathrm{~kJ} \mathrm{~mol}^{-1} \cdot \mathrm{K}^{-1}$ is the molar gas constant, and $f(\alpha)$ is the differential form of reaction mechanism function.

Pyrolysis gas chromatography/mass spectrometry (Py-GC/MS) analysis

The Py-GC/MS was carried out with an EGA/PY3030D device (Frontier, Koriyama, Japan) with a direct connection to a TRACE1310 gas chromatograph (GC) (ThermoFisher, Walsham, MA, USA) equipped with an ISQ mass spectrometer (MS) (ThermoFisher, Walsham, MA, USA). The pyrolysis experiments were conducted at a final temperature of $600{ }^{\circ} \mathrm{C}$ for $12 \mathrm{~s}$ with a heating rate of $1000{ }^{\circ} \mathrm{C} / \mathrm{s}$. High purity helium was used as the carried gas, and the split ratio was $1: 100$. The pyrolytic products were separated using a chromatographic column with DB-5 capillary column $(30 \mathrm{~m} \times 0.25 \mathrm{~mm}$ $\times 0.25 \mu \mathrm{m}$ ) whose temperature was increased from $50{ }^{\circ} \mathrm{C}$ for $2 \mathrm{~min}$, heated up to $320{ }^{\circ} \mathrm{C}$ with a heating rate of $10{ }^{\circ} \mathrm{C} / \mathrm{min}$ and kept constant for $10 \mathrm{~min}$. The MS was performed in an electron ionization mode at $70 \mathrm{eV}$. The pyrolytic products were compared and analyzed according to the NIST library database.

\section{Analytical methods}

The contents of glucan, xylan, and lignin in all the samples were determined by the NREL method (Sluiter et al. 2008). The contents of glucose and xylose were measured with a high performance liquid chromatograph (HPLC) (Shimadzu, Kyoto, Japan) equipped with a refractive index detector (Shimadzu, Kyoto, Japan) and an Aminex HPX$87 \mathrm{H}$ column (Bio-Rad, Hercules, CA, USA). The column temperature was maintained at $65{ }^{\circ} \mathrm{C}$ and $0.6 \mathrm{~mL} / \mathrm{min} 5 \mathrm{mM} \mathrm{H} \mathrm{SO}_{4}$ was employed as the mobile phase. All data were processed by Microsoft Office Excel 2016 (Microsoft, Redmond, WA, USA).

\section{RESULTS AND DISCUSSION}

\section{Formation and Characterization of EHR}

Table 1 lists the chemical composition and enzymatic digestibility of raw and pretreated samples as well as their EHR. The AHP and BHF pretreatments have had distinct impacts on the chemical composition of their EHR. In general, hemicellulose readily dissolves under acidic condition (Sahoo et al. 2018), whereas lignin breaks and degrades under alkaline conditions (Kan et al. 2018). Specifically, after AHP pretreatment, the corn stalk lost $\sim 50 \%$ of its lignin but not as much hemicellulose (5.2\%) according to the yield $(65.66 \%)$ of AHP pretreatment. This is mainly because in the presence hydrogen peroxide under alkaline condition, hydroxide ions can weaken the hydrogen bond between cellulose and hemicellulose and saponify the ester bond between hemicellulose and lignin, to promote the dissolution of hemicellulose and lignin (Yuan et al. 2018). In addition, the hydrogen peroxide ion formed under alkaline condition is strongly oxidative and reacts with the side chains and the chromophores (from oxidized benzene rings) in lignin (Li et al. 2017b). As a result, oxidative cleavage occurs to the lignin side chain, which promotes the dissolution of lignin and reduces the lignin content in the corn stalk after AHP pretreatment (Li et al. 2018).

In contrast, after the BSF pretreatment, the corn stalk lost $\sim 74 \%$ of its hemicellulose but only $\sim 29 \%$ loss of its lignin based on the calculation of the yield $(53.81 \%)$ of BSF pretreatment. The BSF pretreatment provides an acidic environment to degrade and dissolve hemicellulose, and the sodium bisulfite provides $\mathrm{HSO}_{3}{ }^{-}$and $\mathrm{SO}_{3}{ }^{2-}$ ions to degrade 
the lignin groups by sulfonation, i.e., forming soluble sulfonated lignin (Tan et al. 2013). Hence, due to the synergy between sulfite and sulfuric acid in the BSF pretreatment to degrade lignin and hemicellulose, the cellulose becomes better exposed, and the pretreated materials can thus have a much higher efficiency of enzymatic hydrolysis (Tan et al. 2016). The enzymatic hydrolysis results indicated that the AHP and BSF pretreatments evidently increased the conversion rates of glucan to $~ 80 \%$ and $86 \%$, respectively, which were $125 \%$ and $146 \%$ higher than those of the untreated sample.

Table 1 also shows the residual percentage and chemical composition of the EHR. The results showed that the residual percentage of AHP-EHR and BSF-EHR was 35.8\% and $42.1 \%$, respectively. Thus, most of the solid after pretreatment was degraded by cellulase, and the content of cellulose and hemicellulose was dramatically decreased in the EHR, hence increasing the relative content of lignin. Nevertheless, AHP and BSF had distinct pretreatment mechanisms, and the chemical components of AHP-EHR and BSFEHR were different. The subsequent pyrolysis of each EHR was thus unique.

Table 1. Chemical Compositions and Enzymatic Digestibility of Corn Stalk

\begin{tabular}{|c|c|c|c|c|c|}
\hline Samples & $\begin{array}{c}\text { Residual } \\
\text { Rate }(\%)\end{array}$ & $\begin{array}{c}\text { Glucan (\%) } \\
(\% \text { loss })\end{array}$ & $\begin{array}{c}\text { Xylan (\%) } \\
(\% \text { loss })\end{array}$ & $\begin{array}{c}\text { Total Lignin } \\
(\%)(\% \text { loss })\end{array}$ & $\begin{array}{c}48 \mathrm{~h} \text { Glucan } \\
\text { Conversion } \\
(\%)\end{array}$ \\
\hline Corn Stalk & - & $27.85 \pm 1.23$ & $13.52 \pm 0.82$ & $19.37 \pm 0.65$ & $35.04 \pm 0.41$ \\
\hline AHP-S & - & $\begin{array}{c}39.38 \pm 0.12 \\
(7.16)\end{array}$ & $\begin{array}{c}19.52 \pm 0.09 \\
(5.20)\end{array}$ & $\begin{array}{c}15.28 \pm 0.21 \\
(48.20)\end{array}$ & $78.92 \pm 0.53$ \\
\hline BSF-S & - & $\begin{array}{c}50.03 \pm 0.85 \\
(3.34)\end{array}$ & $\begin{array}{c}6.53 \pm 0.07 \\
(74.01)\end{array}$ & $\begin{array}{c}25.57 \pm 0.57 \\
(28.97)\end{array}$ & $86.08 \pm 1.39$ \\
\hline AHP-EHR & 35.81 & $36.29 \pm 3.02$ & $17.45 \pm 1.01$ & $32.77 \pm 1.09$ & - \\
\hline BSF-EHR & 42.14 & $14.06 \pm 1.22$ & $3.81 \pm 0.08$ & $52.52 \pm 1.79$ & - \\
\hline
\end{tabular}

\section{Pyrolysis of the EHR by TG-IR}

The TG and DTG curves of the EHR (Fig. 1) clearly show three stages: dehydration, rapid pyrolysis, and carbonization. The first is the dehydration stage from 40 ${ }^{\circ} \mathrm{C}$ to $180{ }^{\circ} \mathrm{C}$, in which the derivative thermogravimetric (DTG) curve shows one weight loss peak, and the maximum weight loss rate appears at approximately 66 to $72{ }^{\circ} \mathrm{C}$. This stage is mainly about the loss of water (Amaral et al. 2019). In this stage, the TG curve showed a small mass loss ( 3 to $4.5 \mathrm{wt} \%$ ), which means that there was a low moisture content of the EHR. The second stage was rapid pyrolysis. Hemicellulose has a relatively low pyrolysis temperature of 230 to $330{ }^{\circ} \mathrm{C}$, probably because of the instability of its amorphous structure (Kruse et al. 2013). The pyrolysis of cellulose took place at a slightly higher temperature $\left(260\right.$ to $\left.400{ }^{\circ} \mathrm{C}\right)$. The pyrolysis of lignin takes place over a wide range from 300 to $700{ }^{\circ} \mathrm{C}$ because the lignin structure is highly complex, and lignin is relatively stable (Long et al. 2014). On the TG curve, the weight loss of the AHP-EHR occurred firstly at 180 to $370{ }^{\circ} \mathrm{C}$, possibly due to the decomposition of hemicelluloses as the AHP pretreatment mainly removed lignin and partly removed hemicelluloses. The shoulder peak at approximately $290^{\circ} \mathrm{C}$ in the DTG curve of AHP-EHR also came from the decomposition of hemicellulose. For the pyrolysis of both AHP-EHR and BSF-EHR, the maximum weight loss rate occurred around $355^{\circ} \mathrm{C}$, which may have been related to the decomposition of cellulose. The difference in the weight loss rate may be attributed to particular features of lignocellulose destruction by different pretreatment methods. Still, both pretreatments had 
nearly the same effect on the cellulose components in the EHR. In the TG curve, the mass loss amounted to $50.3 \%$ for AHP-EHR and $40.7 \%$ for BSF-EHR in the second stage, and the former was $23.5 \%$ higher than the latter. The weight loss peak of BSF-EHR in 370 to $610{ }^{\circ} \mathrm{C}$ may be related to the decomposition of lignin. In comparison, AHP-EHR had a wider temperature range of decomposition and its cumulative weight loss amounted to $37.1 \%$, BSF-EHR had a narrower temperature range of decomposition, and its cumulative weight loss amounted to $43.3 \%$. The third stage $\left(610\right.$ to $\left.800{ }^{\circ} \mathrm{C}\right)$ was the carbonization of EHR, for which the slow decomposition produced few volatile products from lignin, and the content of residual biochar was high. After this stage, the AHP-EHR had $8.27 \mathrm{wt} \%$ whereas the BSF-EHR had $12.76 \mathrm{wt} \%$ weight left. The residual mass was lower for AHPEHR because AHP removed a greater amount of lignin than BSF pretreatment. The DTG curve in this stage was relatively flat and showed no more obvious peaks of weight loss.
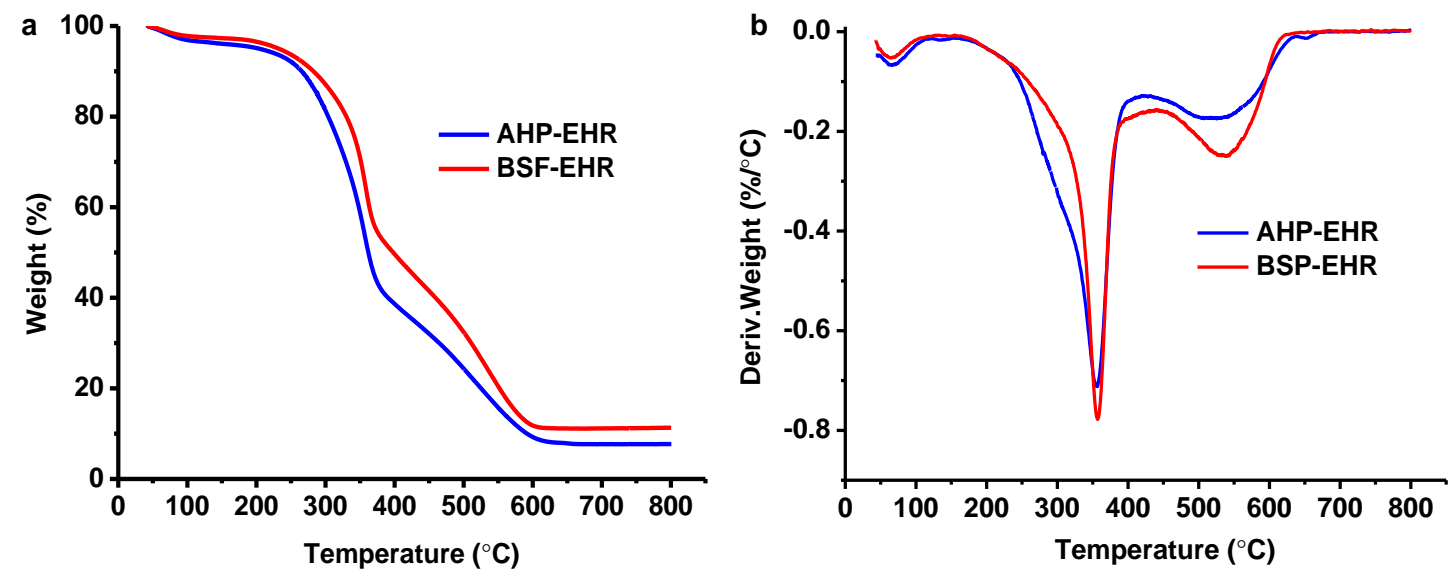

Fig. 1. TG (a) and DTG (b) curves of the EHR

\section{TG-IR Analysis of Gaseous Products}

Figure 2 shows the infrared spectrum of the EHR at the highest pyrolysis rate (355 $\left.{ }^{\circ} \mathrm{C}\right)$. According to the Lambert-Beer law, the change of absorbance in the entire pyrolysis process can reflect the variation of the relative content of the gaseous products ( $\mathrm{Gu}$ et al. 2013).

The IR peak at 3400 to $4000 \mathrm{~cm}^{-1}$ corresponds to the $\mathrm{O}-\mathrm{H}$ stretching vibration of $\mathrm{H}_{2} \mathrm{O}$ and may be related to the cleavage of residual polysaccharides and the shedding and reorganization of aliphatic hydroxyl groups on the side chains of lignin (Cao et al. 2013). The $\mathrm{C}-\mathrm{H}$ stretching vibration peak at 2650 to $3160 \mathrm{~cm}^{-1}$ indicated the presence of alkane compounds in the volatiles, possibly from the lysis of methoxy $\left(\mathrm{CH}_{3} \mathrm{O}-\right)$ and methylene ($\mathrm{CH}_{2}$ ) components in lignin at high temperature. The intensity of the $\mathrm{C}-\mathrm{H}$ stretching vibration peak was higher in the AHP-EHR than in the BSF-EHR, possibly because the AHP pretreatment exposed more methoxyl groups in the lignin components and accelerated the decomposition of lignin. The $\mathrm{C}=\mathrm{O}$ stretching vibration peak of $\mathrm{CO}_{2}$ at 2260 to $2400 \mathrm{~cm}^{-1}$ is mainly derived from the carboxyl groups on the side chain of the lignin structure (Ren et al. 2009). The absorption peak of CO at 2145 to $2225 \mathrm{~cm}^{-1}$ mainly resulted from the cleavage of $\mathrm{C}-\mathrm{O}-\mathrm{C}$ in lignin units. The deep thermal cracking at the higher temperature of the tars generated from low-temperature pyrolysis then yielded small molecules such as CO. Within 1650 to $1850 \mathrm{~cm}^{-1}$, the peak at $1745 \mathrm{~cm}^{-1}$ was mainly the stretching vibration absorption peak of carbonyl $(\mathrm{C}=\mathrm{O})$ groups and indicated that the 
pyrolysis gas may contain aldehydes and ketones that came from the degradation of lignin. The peaks in 1650 to $1470 \mathrm{~cm}^{-1}$ mainly came from the $\mathrm{C}=\mathrm{C}$ stretching vibration and the vibration of the benzene ring skeleton, and the absorption peak at $1510 \mathrm{~cm}^{-1}$ indicated the presence of aromatic compounds in the volatiles. Although the characteristic absorption peaks of different substances overlapped with each other in 1000 to $1470 \mathrm{~cm}^{-1}$ and made it difficult to distinguish specific components, functional groups can still be categorically identified from their characteristic absorption peaks (Chen et al. 2015). For example, the characteristic absorption peaks at 1365 to $1460 \mathrm{~cm}^{-1}$ are mainly the methyl $\left(-\mathrm{CH}_{3}\right)$ and methylene groups $\left(-\mathrm{CH}_{2}-\right)$ of alkanes. The peaks at 1000 to $1200 \mathrm{~cm}^{-1}$ likely come from alcohol, 1200 to $1300 \mathrm{~cm}^{-1}$ from phenol, 1060 to $1275 \mathrm{~cm}^{-1}$ from the aromatic ether, and 1050 to $1300 \mathrm{~cm}^{-1}$ from the ester. Because in the BSF pretreatment, lignin was sulfonated, and some phenolic hydroxyl groups were replaced by sulfonyl groups, BSF-EHR produced less $\mathrm{H}_{2} \mathrm{O}, \mathrm{CO}$, and $\mathrm{CO}_{2}$ from pyrolysis than AHP-EHR.

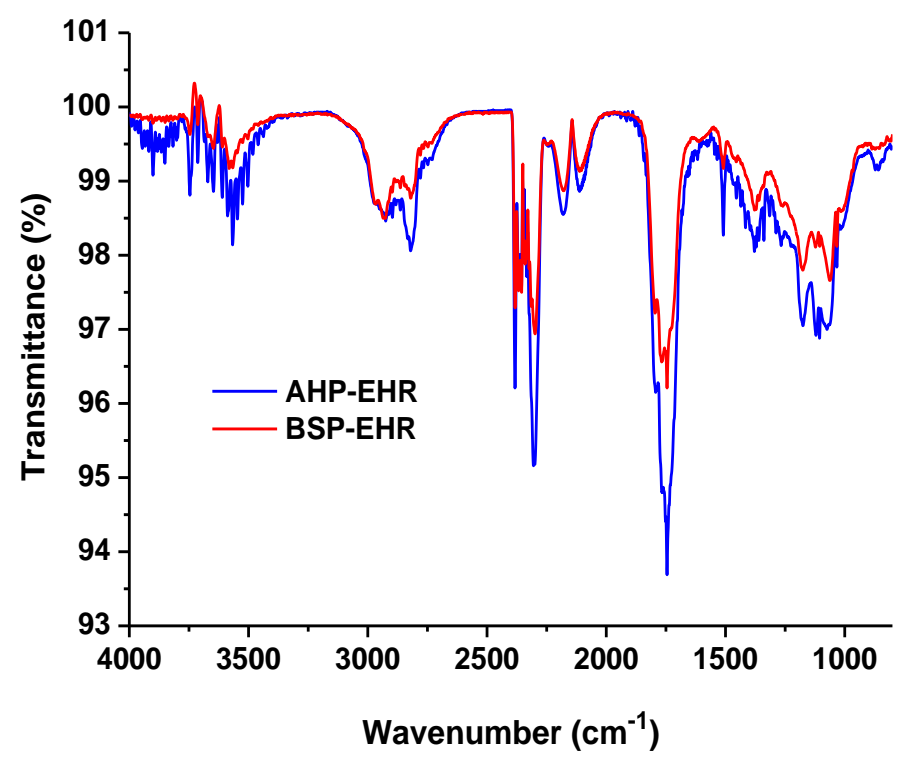

Fig. 2. IR spectra of the $E H R$ as heated at $355^{\circ} \mathrm{C}$ during the $T G$ analysis

\section{The Kinetics of EHR Pyrolysis}

Data processing of the pyrolysis reaction rate equation can adopt either the differential method or the integral method (Mishra and Mohanty 2018). The differential method used the value from the DTG curve. Because the DTG curve was easily affected by various external factors, kinetic parameters determined by the differential method tend to have poor accuracy. In contrast, the integration method directly used the value from the TG curve. The result was not easily affected, and the calculation tended to be accurate and simple because the instantaneous change of the TG curve was smaller. Common integration methods include the Doyle method, the MacCallum-Tammer method, the Flynn-WallOzawa method (FWO method), the Coats-Redfern method, etc. (Gil et al. 2010). Among these, the Coats-Redfern method is relatively simple and has good accuracy. It is used here to determine the activation energy $E$ and frequency factor $A$ of the kinetic parameters of the pyrolysis, a non-isothermal chemical reaction (Jayaraman et al. 2017).

Let $G(\alpha)$ be the integral form of the mechanism function and its relationship with $f(\alpha)$ as follows: 


$$
\mathrm{f}(\alpha)=\frac{1}{G^{\prime}(\alpha)}=\frac{1}{d[G(\alpha)] / d \alpha}
$$

That is:

$$
\mathrm{G}(\alpha)=\int_{0}^{\alpha} \frac{d \alpha}{\mathrm{f}(\alpha)}
$$

Because Eq. 8 can be expressed alternatively as $\frac{d \alpha}{f(\alpha)}=\frac{\mathrm{A}}{\beta} \exp \left(-\frac{E}{R T}\right) d T$, we have:

$$
\mathrm{G}(\alpha)=\frac{\mathrm{A}}{\beta} \int_{0}^{T} \exp \left(\frac{-E}{R T}\right) d T
$$

According to the Coats-Redfern method:

$$
\int_{0}^{T} \exp \left(\frac{-E}{R T}\right) d T \approx \frac{R T^{2}}{E}\left(1-\frac{2 R T}{E}\right) \exp \left(\frac{-E}{R T}\right)
$$

After substituting Eq. 12 into Eq. 11, further simplification gives:

$$
\ln \left[\frac{\mathrm{G}(\alpha)}{\mathrm{T}^{2}}\right]=\ln \left[\frac{A R}{\beta E}\left(1-\frac{2 R T}{E}\right)\right]-\frac{E}{R T}
$$

Because $E \gg R T$ and $1-(2 R T / E) \approx 1$ for most temperature ranges of pyrolysis and combustion reactions, Eq. 13 can be further simplified as:

$$
\ln \left[\frac{G(\alpha)}{T^{2}}\right]=\ln \left(\frac{A R}{\beta E}\right)-\frac{E}{R T}
$$

Therefore, with an expression of $G(\alpha)$ that describes the pyrolysis reaction correctly, a linear relationship can be established between $\ln \left[G(\alpha) / T^{2}\right]$ and $1 / T$, the slope and intercept of which will allow the calculation of the activation energy $E$ and the frequency factor $A$.

Because the thermal decomposition rate was small in the first and the third stages of pyrolysis, the kinetic calculations targeted only on the second stage. The TG curve in the second stage exhibited two distinct weight losses that can be further divided into two intervals, i.e., 180 to $370{ }^{\circ} \mathrm{C}$ and 370 to $620{ }^{\circ} \mathrm{C}$. Different pyrolysis mechanism functions were then used for fitting, and in each interval, the activation energy $E$ and frequency factor $A$ were determined based on the fitting results that maximized the correlation coefficient $\left(\mathrm{R}^{2}\right)$. The activation energy represents the minimum energy required for a chemical reaction to occur, i.e., the reaction occurs less easily, or the reaction rate is lower when the activation energy is higher.

Table 2. Activation Energy and Arrhenius Constants Obtained Using CoatsRedfern Method

\begin{tabular}{|l|c|c|c|c|c|}
\hline Samples & $\begin{array}{c}\text { Temperature } \\
\text { Range }\left({ }^{\circ} \mathrm{C}\right)\end{array}$ & Kinetics Pattern & $E(\mathrm{~kJ} / \mathrm{mol})$ & $A\left(\mathrm{~min}^{-1}\right)$ & $\mathrm{R}^{2}$ \\
\hline \multirow{2}{*}{ AHP-EHR } & 180 to 370 & D1 & 60.98 & $2.36 \times 10^{3}$ & 0.948 \\
\cline { 2 - 6 } & 370 to 620 & D2 & 15.31 & 5.51 & 0.978 \\
\hline \multirow{2}{*}{ BSF-EHR } & 180 to 370 & D1 & 59.71 & $8.27 \times 10^{3}$ & 0.960 \\
\cline { 2 - 6 } & 370 to 610 & D1 & 15.55 & 32.56 & 0.990 \\
\hline
\end{tabular}

Table 2 shows that the pyrolysis of AHP-EHR conformed to the D1 (onedimensional diffusion) model in 180 to $370{ }^{\circ} \mathrm{C}$ and to the $\mathrm{D} 2$ (two-dimensional diffusion) 
model in 370 to $620{ }^{\circ} \mathrm{C}$. However, BSF-EHR conformed to the D1 model in the whole second stage $\left(180\right.$ to $\left.610^{\circ} \mathrm{C}\right)$. The activation energy of the pyrolysis of AHP-EHR was $61.0 \mathrm{~kJ} / \mathrm{mol}$ for 180 to $370{ }^{\circ} \mathrm{C}$ and $15.3 \mathrm{~kJ} / \mathrm{mol}$ for 370 to $620^{\circ} \mathrm{C}$. The activation energy of the pyrolysis of BSF-EHR was $59.7 \mathrm{~kJ} / \mathrm{mol}$ for 180 to $370{ }^{\circ} \mathrm{C}$ and $15.6 \mathrm{~kJ} / \mathrm{mol}$ for 370 to $610^{\circ} \mathrm{C}$. The observed difference can be attributed to the higher lignin content and slightly lower hemicellulose content of AHP-EHR than BSF-EHR (Table 1).

\section{Py-GC/MS Analysis}

The Py-GC/MS analysis for EHR was conducted mainly to identify more detailed information about the byproducts of fast pyrolysis (Huang et al. 2020). The main byproducts of the AHP-EHR and BSF-EHR pyrolysis identified via Py-GC/MS are shown in Table 3, while their chromatograms are given in Fig. 3.

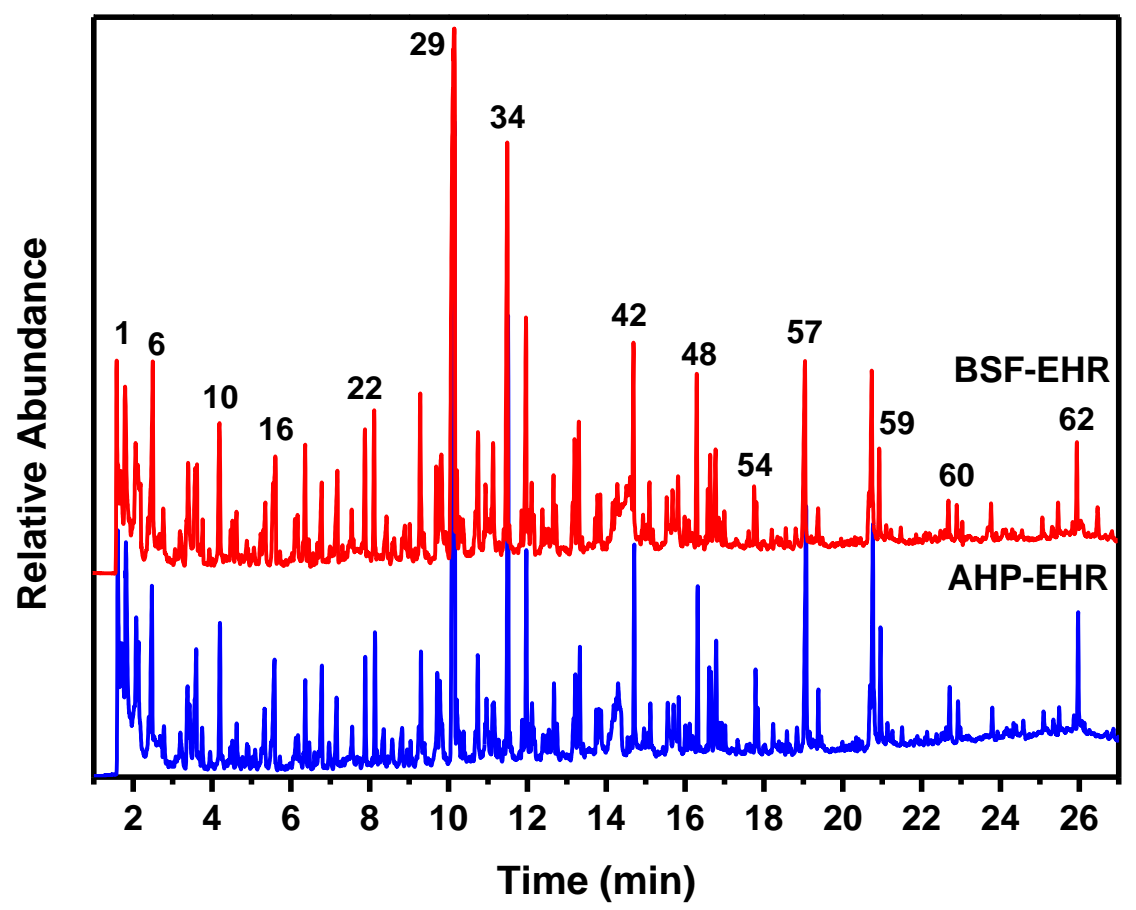

Fig. 3. Py-GC/MS detection of gas products evolved from the pyrolysis

A total of 59 and 61 compounds were identified for the AHP-EHR than BSF-EHR pyrolysis, respectively. The identified compounds were classified as phenols, furans, acids, nitrides, ketones, esters, alcohols, aldehydes, and others. Phenols, furans, and acids were the main byproducts of the AHP-EHR and BSF-EHR pyrolysis, whose sum accounted for $52.3 \%$ and $53.5 \%$ of the total compounds, respectively (Fig. 4). Phenols in the AHP-EHR pyrolysis process mainly contained 2-methoxy-4-vinylphenol (4.69\%), 4-ethenyl-2,6dimethoxy-phenol (1.77\%), and 2,6-dimethoxy-phenol (1.67\%), while furans mainly included 2,3-dihydro-benzofuran (13.65\%) and furfural (1.59\%). In contrast, phenols in the BSF-EHR pyrolysis process mainly contained 2-methoxy-4-vinylphenol (4.55\%), catechol (2.31\%), and 2,6-dimethoxy-phenol (2.18\%), while furans mainly included 2,3dihydro-benzofuran $(12.03 \%)$, furfural $(1.9 \%)$, and 5-hydroxymethylfurfural $(0.34 \%)$. It was reported that phenolic derivatives of the pyrolysis byproducts primarily derive from its lignin component of the biomass (Ming et al. 2020). The higher phenol content of BSF- 
EHR (30.68\%) than AHP-EHR (26.75\%) was attributed to the higher lignin content of BSF-EHR than AHP-EHR, which was consistent with the chemical components shown in Table 1. The furan-related compounds in the pyrolysis byproducts were most likely originating from the open-ring reactions and the dehydration of (hemi)cellulose. The AHPEHR had a higher content of furan-related compounds (15.24\%) than BSF-EHR (14.27\%). Acids were also the main byproducts in this study, which were probably due to the degradation of hemicellulose. The acids contents of the AHP-EHR and BSF-EHR byproducts were $10.33 \%$ and $8.52 \%$, respectively, which was supported by the chemical component in Table 1. Ketones and aldehydes were also detected during EHR pyrolysis, which was demonstrated to be derived from the decomposition of cellulose (Akalın and Karagöz 2014). Nitrides were also found in the pyrolysis of AHP-EHR and BSF-EHR as $9.35 \%$ and $4.84 \%$, respectively. Nitrides are probably formed from the Maillard reactions of the carbonyl and amino functional groups of protein (Li et al. 2016). Moreover, esters and alcohols were also detected, while the relative contents of these compounds were each less than $2 \%$.

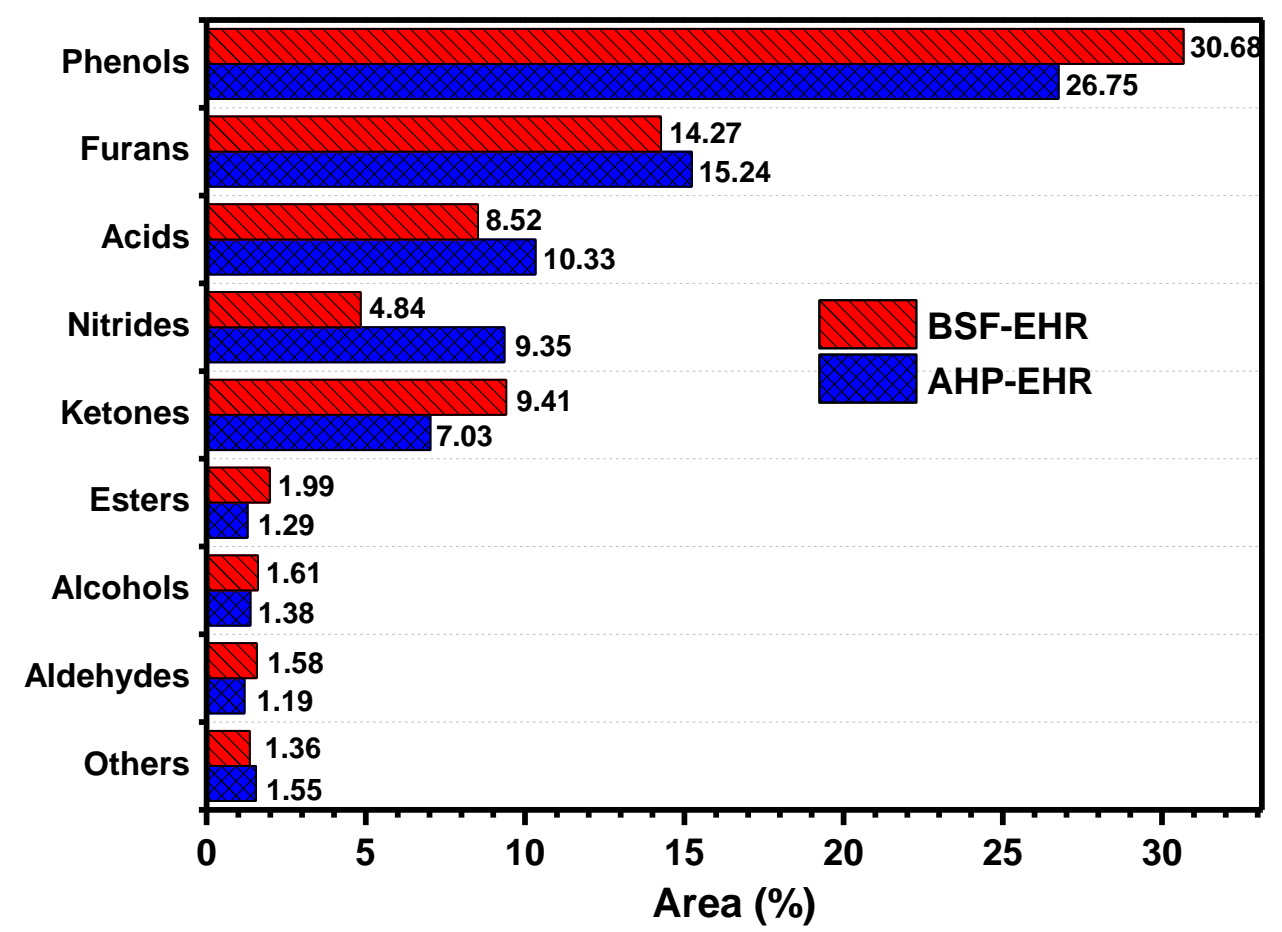

Fig. 4. The relative content of different species for AHP-EHR and BSF-EHR

Overall, cellulose and hemicellulose were shown to exhibit the depolymerization, dehydration to pyran or furan derivatives, and then the ring-breakage to light oxygenated compounds of pyranose or furanose. Lignin, made of different kinds of phenyl-propane units, showed intense structural transformations, including side-chain bond breakage, recondensation, and hydroxymethyl removal. However, the benzene ring is not easy to break during pyrolysis (Liang et al. 2018). The resultant pyrolysis products can be used as the main chemical substances and bioenergy intermediates. 
Table 3. Main Byproducts of the AHP-EHR and BSF-EHR Pyrolysis Identified by $\mathrm{Py}-\mathrm{GC} / \mathrm{MS}$

\begin{tabular}{|c|c|c|c|c|c|c|c|}
\hline \multirow[t]{2}{*}{ No. } & \multirow[t]{2}{*}{ Compound } & \multirow[t]{2}{*}{ Formula } & \multirow[t]{2}{*}{ Group } & \multicolumn{2}{|c|}{ AHP-EHR } & \multicolumn{2}{|c|}{ BSF-EHR } \\
\hline & & & & $\begin{array}{l}\mathrm{RT} \\
(\min )\end{array}$ & $\begin{array}{l}\text { Area } \\
(\%)\end{array}$ & $\begin{array}{l}\mathrm{RT} \\
(\min )\end{array}$ & $\begin{array}{c}\text { Area } \\
(\%)\end{array}$ \\
\hline 1 & Malonamic acid & $\mathrm{C}_{3} \mathrm{H}_{5} \mathrm{NO}_{3}$ & Nitrides & 1.70 & 2.56 & 1.71 & 1.05 \\
\hline 2 & (4-Aminobutyl) guanidine & $\mathrm{C}_{5} \mathrm{H}_{14} \mathrm{~N}_{4}$ & Nitrides & 1.82 & 3.43 & 1.83 & 2.14 \\
\hline 3 & (4-Aminobutyl) guanidine & $\mathrm{C}_{5} \mathrm{H}_{14} \mathrm{~N}_{4}$ & Nitrides & 2.08 & 2.65 & 2.10 & 1.04 \\
\hline 4 & Acetic acid & $\mathrm{C}_{2} \mathrm{H}_{4} \mathrm{O}_{2}$ & Acids & - & - & 2.21 & 0.66 \\
\hline 6 & 2-Propanone & $\mathrm{C}_{3} \mathrm{H}_{6} \mathrm{O}_{2}$ & Ketones & 2.47 & 1.88 & 2.53 & 2.41 \\
\hline 7 & $\begin{array}{l}\text { 1-(Tetrahydro-2H-pyran-4- } \\
\text { yl) piperidin-4-amine }\end{array}$ & $\mathrm{C}_{10} \mathrm{H}_{20} \mathrm{~N}_{2} \mathrm{O}$ & Nitrides & 3.20 & 0.71 & 3.22 & 0.61 \\
\hline 8 & Acetic acid & $\mathrm{C}_{4} \mathrm{H}_{6} \mathrm{O}_{4}$ & Acids & 3.37 & 0.77 & - & - \\
\hline 9 & Heptyl 2-phenylacetate & $\mathrm{C}_{15} \mathrm{H}_{22} \mathrm{O}_{2}$ & Esters & 3.43 & 0.66 & 3.43 & 1.41 \\
\hline 10 & Propanoic acid & $\mathrm{C}_{4} \mathrm{H}_{6} \mathrm{O}_{3}$ & Acids & 3.59 & 1.73 & 3.61 & 1.72 \\
\hline 11 & Furfural & $\mathrm{C}_{5} \mathrm{H}_{4} \mathrm{O}_{2}$ & Furans & 4.20 & 1.59 & 4.22 & 1.9 \\
\hline 12 & 2-Butanone & $\mathrm{C}_{4} \mathrm{H}_{8} \mathrm{O}$ & Ketones & 4.52 & 0.22 & 4.55 & 0.58 \\
\hline 13 & Acetoxy-2-propanone & $\mathrm{C}_{5} \mathrm{H}_{8} \mathrm{O}_{3}$ & Ketones & 4.62 & 0.52 & 4.65 & 0.57 \\
\hline 14 & 4-Cyclopentene-1,3-dione & $\mathrm{C}_{5} \mathrm{H}_{4} \mathrm{O}_{2}$ & Ketones & 4.89 & 0.42 & 4.92 & 0.40 \\
\hline 15 & 2(5H)-Furanone & $\mathrm{C}_{4} \mathrm{H}_{4} \mathrm{O}_{2}$ & Ketones & 5.33 & 0.85 & 5.38 & 0.98 \\
\hline 16 & 2-Cyclopenten-1-one & $\mathrm{C}_{5} \mathrm{H}_{6} \mathrm{O}_{2}$ & Ketones & 5.57 & 1.68 & 5.63 & 2.24 \\
\hline 17 & Phenol & $\mathrm{C}_{6} \mathrm{H}_{6} \mathrm{O}$ & Phenols & 6.36 & 0.85 & 6.39 & 1.18 \\
\hline 18 & $\begin{array}{c}\text { 2-hydroxy-3- } \\
\text { methylcyclopent-2-en-1-one }\end{array}$ & $\mathrm{C}_{6} \mathrm{H}_{8} \mathrm{O}_{2}$ & Ketones & 7.16 & 0.83 & 7.20 & 1.41 \\
\hline 19 & $\begin{array}{l}\text { 2,3-dimethylcyclopent-2-en- } \\
\text { 1-one }\end{array}$ & $\mathrm{C}_{7} \mathrm{H}_{10} \mathrm{O}$ & Ketones & 7.33 & 0.04 & 7.34 & 0.12 \\
\hline 20 & 2-methyl-phenol & $\mathrm{C}_{7} \mathrm{H}_{8} \mathrm{O}$ & Phenols & 7.55 & 0.52 & 7.57 & 0.60 \\
\hline 21 & 4-methyl-phenol & $\mathrm{C}_{7} \mathrm{H}_{8} \mathrm{O}$ & Phenols & 7.89 & 1.00 & 7.91 & 1.26 \\
\hline 22 & 2-methoxy-phenol & $\mathrm{C}_{7} \mathrm{H}_{8} \mathrm{O}_{2}$ & Phenols & 8.13 & 1.08 & 8.14 & 1.32 \\
\hline 23 & Cyclopropyl carbinol & $\mathrm{C}_{4} \mathrm{H}_{8} \mathrm{O}$ & Alcohols & 8.35 & 0.55 & 8.46 & 0.77 \\
\hline 24 & $\begin{array}{c}\text { 1-Deoxy-1-(methylamino)- } \\
\text { D-galactitol }\end{array}$ & $\mathrm{C}_{7} \mathrm{H}_{17} \mathrm{NO}_{5}$ & Alcohols & 8.82 & 0.63 & 8.91 & 0.68 \\
\hline 25 & 2,4-dimethyl-phenol & $\mathrm{C}_{8} \mathrm{H}_{10} \mathrm{O}$ & Phenols & 9.04 & 0.27 & 9.05 & 0.28 \\
\hline 26 & 4-ethyl-phenol & $\mathrm{C}_{8} \mathrm{H}_{10} \mathrm{O}$ & Phenols & 9.30 & 1.49 & 9.31 & 1.82 \\
\hline 27 & Creosol & $\mathrm{C}_{8} \mathrm{H}_{10} \mathrm{O}_{2}$ & Phenols & 9.71 & 0.87 & 9.72 & 0.74 \\
\hline 28 & Catechol & $\mathrm{C}_{6} \mathrm{H}_{6} \mathrm{O}_{2}$ & Phenols & 9.78 & 1.29 & 9.84 & 2.31 \\
\hline 29 & 2,3-dihydro-benzofuran & $\mathrm{C}_{8} \mathrm{H}_{8} \mathrm{O}$ & Furans & 10.14 & 13.65 & 10.17 & 12.03 \\
\hline 30 & 5-Hydroxymethylfurfural & $\mathrm{C}_{6} \mathrm{H}_{6} \mathrm{O}_{3}$ & Furans & - & - & 10.31 & 0.34 \\
\hline
\end{tabular}




\begin{tabular}{|c|c|c|c|c|c|c|c|}
\hline 31 & $\begin{array}{l}\text { 1,3-methoxy-1,2- } \\
\text { benzenedio }\end{array}$ & $\mathrm{C}_{7} \mathrm{H}_{8} \mathrm{O}_{3}$ & Phenols & 10.74 & 1.25 & 10.78 & 1.62 \\
\hline 32 & 4-ethyl-2-metho phenol & $\mathrm{C}_{9} \mathrm{H}_{12} \mathrm{O}_{2}$ & Phenols & 10.96 & 0.92 & 10.97 & 0.65 \\
\hline 33 & I, 4-methyl-1,2-benzenedio & $\mathrm{C}_{7} \mathrm{H}_{8} \mathrm{O}_{2}$ & Phenols & 11.14 & 1.00 & 11.16 & 1.50 \\
\hline 34 & 2-methoxy-4-vinylphenol & $\mathrm{C}_{9} \mathrm{H}_{10} \mathrm{O}_{2}$ & Phenols & 11.51 & 4.69 & 11.52 & 4.55 \\
\hline 35 & 2,6-dimethoxy-phenol & $\mathrm{C}_{8} \mathrm{H}_{10} \mathrm{O}_{3}$ & Phenols & 11.97 & 1.67 & 11.99 & 2.18 \\
\hline 36 & 3,4-dimethoxy-phenol & $\mathrm{C}_{8} \mathrm{H}_{10} \mathrm{O}_{3}$ & Phenols & 12.12 & 0.80 & 12.14 & 0.90 \\
\hline 37 & $\begin{array}{l}\text { 3-hydroxy-4-methoxy- } \\
\text { benzaldehyde }\end{array}$ & $\mathrm{C}_{8} \mathrm{H}_{8} \mathrm{O}_{3}$ & Aldehydes & 12.67 & 0.70 & 12.69 & 0.67 \\
\hline 38 & $\begin{array}{l}\text { 2-methoxy-5-(1-propenyl)- } \\
\text { (E)-phenol }\end{array}$ & $\mathrm{C}_{10} \mathrm{H}_{12} \mathrm{O}_{2}$ & Phenols & 12.75 & 0.32 & 12.76 & 0.38 \\
\hline 39 & $\begin{array}{l}\text { 3,5-dimethoxy-4- } \\
\text { hydroxytoluene }\end{array}$ & $\mathrm{C}_{9} \mathrm{H}_{12} \mathrm{O}_{3}$ & Phenols & 13.21 & 1.21 & 13.23 & 1.55 \\
\hline 40 & $\begin{array}{l}\text { 2-methoxy-4-(1-propenyl)- } \\
\text { phenol }\end{array}$ & $\mathrm{C}_{10} \mathrm{H}_{12} \mathrm{O}_{2}$ & Phenols & 13.33 & 0.98 & 13.34 & 1.20 \\
\hline 41 & 4-(1-butenyl)guaiacol & $\mathrm{C}_{11} \mathrm{H}_{14} \mathrm{O}_{2}$ & Phenols & 14.54 & 0.11 & 14.55 & 0.23 \\
\hline 42 & $\begin{array}{l}\text { 4-ethenyl-2,6-dimethoxy- } \\
\text { phenol }\end{array}$ & $\mathrm{C}_{10} \mathrm{H}_{12} \mathrm{O}_{3}$ & Phenols & 14.71 & 1.77 & 14.72 & 1.51 \\
\hline 43 & $\begin{array}{l}\text { 2,6-dimethoxy-4-(2- } \\
\text { propenyl)-phenol }\end{array}$ & $\mathrm{C}_{11} \mathrm{H}_{14} \mathrm{O}_{3}$ & Phenols & 15.12 & 0.49 & 15.13 & 0.53 \\
\hline 44 & $\begin{array}{l}\text { 1-(4-Methoxy-2- } \\
\text { nitroanilino)-1-deoxy-a-d- } \\
\text { arabinofuranose }\end{array}$ & $\mathrm{C}_{12} \mathrm{H}_{16} \mathrm{~N}_{2} \mathrm{O}_{7}$ & Others & - & - & 15.21 & 0.21 \\
\hline 45 & 6-Hydroxyeugenol & $\mathrm{C}_{10} \mathrm{H}_{12} \mathrm{O}_{3}$ & Phenols & 15.56 & 0.72 & 15.57 & 0.72 \\
\hline 46 & $\begin{array}{c}\text { (E)-2,6-Dimethoxy-4-(prop- } \\
\text { 1-en-1-yl) phenol }\end{array}$ & $\mathrm{C}_{11} \mathrm{H}_{14} \mathrm{O}_{3}$ & Phenols & 15.71 & 0.57 & 15.71 & 0.69 \\
\hline 47 & $\begin{array}{l}\text { 4-hydroxy-3,5- } \\
\text { benzaldehyde }\end{array}$ & $\mathrm{C}_{9} \mathrm{H}_{10} \mathrm{O}_{4}$ & Aldehydes & 15.84 & 0.49 & 15.85 & 0.91 \\
\hline 48 & $\begin{array}{l}\text { 2,6-dimethoxy-4-(2- } \\
\text { propenyl)-phenol }\end{array}$ & $\mathrm{C}_{11} \mathrm{H}_{14} \mathrm{O}_{3}$ & Phenols & 16.32 & 1.27 & 16.33 & 1.37 \\
\hline 49 & $\begin{array}{c}\text { 1-(4-hydroxy-3,5- } \\
\text { dimethoxyphenyl)-ethanone }\end{array}$ & $\mathrm{C}_{10} \mathrm{H}_{12} \mathrm{O}_{4}$ & Ketones & 16.66 & 0.59 & 16.67 & 0.70 \\
\hline 50 & $\begin{array}{c}\text { (E)-4-(3-Hydroxyprop-1-en- } \\
\text { 1-yl)-2-methoxy phenol }\end{array}$ & $\mathrm{C}_{10} \mathrm{H}_{12} \mathrm{O}_{3}$ & Phenols & 16.78 & 1.11 & 16.80 & 0.95 \\
\hline 51 & $\begin{array}{l}\text { 2-Propenoic acid, 3-(4-hydr } \\
\text {-oxyphenyl)-, methylester }\end{array}$ & $\mathrm{C}_{10} \mathrm{H}_{10} \mathrm{O}_{3}$ & Esters & 16.87 & 0.20 & 16.88 & 0.23 \\
\hline 52 & Tetradecanoic acid & $\mathrm{C}_{14} \mathrm{H}_{28} \mathrm{O}_{2}$ & Acids & 16.93 & 0.19 & 16.93 & 0.15 \\
\hline 53 & Syringylacetone & $\mathrm{C}_{11} \mathrm{H}_{14} \mathrm{O}_{4}$ & Phenols & 17.02 & 0.19 & 17.03 & 0.29 \\
\hline 54 & Neophytadiene & $\mathrm{C}_{20} \mathrm{H}_{38}$ & Others & 17.79 & 0.59 & 17.78 & 0.40 \\
\hline 55 & Trans-sinapylalcohol & $\mathrm{C}_{11} \mathrm{H}_{14} \mathrm{O}_{4}$ & Alcohols & 18.58 & 0.20 & 18.59 & 0.16 \\
\hline 56 & Palmitoleic acid & $\mathrm{C}_{16} \mathrm{H}_{30} \mathrm{O}_{2}$ & Acids & 18.84 & 0.34 & 18.84 & 0.29 \\
\hline 57 & n-Hexadecanoic acid & $\mathrm{C}_{16} \mathrm{H}_{32} \mathrm{O}_{2}$ & Acids & 19.06 & 3.24 & 19.07 & 2.50 \\
\hline 58 & Oleic acid & $\mathrm{C}_{18} \mathrm{H}_{34} \mathrm{O}_{2}$ & Acids & 20.76 & 3.01 & 20.76 & 2.41 \\
\hline 59 & Octadecanoic acid & $\mathrm{C}_{18} \mathrm{H}_{36} \mathrm{O}_{2}$ & Acids & 20.96 & 1.05 & 20.96 & 0.79 \\
\hline 60 & $\begin{array}{l}\text { Hexanedioic acid, bis(2- } \\
\text { ethylhexyl) ester }\end{array}$ & $\mathrm{C}_{22} \mathrm{H}_{42} \mathrm{O}_{4}$ & Esters & 22.92 & 0.43 & 22.92 & 0.35 \\
\hline
\end{tabular}




\begin{tabular}{|c|c|c|c|c|c|c|c|}
\hline 61 & $\begin{array}{c}4,4 \text { '-methylenebis[2,6- } \\
\text { dimethoxy-phenol }\end{array}$ & $\mathrm{C}_{17} \mathrm{H}_{20} \mathrm{O}_{6}$ & Phenols & 25.49 & 0.31 & 25.50 & 0.35 \\
\hline 62 & $(\mathrm{Z})-13$-Docosenamide & $\mathrm{C}_{22} \mathrm{H}_{43} \mathrm{NO}$ & Others & 25.97 & 0.96 & 25.97 & 0.75 \\
\hline RT: Retention time (min)
\end{tabular}

\section{CONCLUSIONS}

1. The pyrolysis behaviors, kinetics, and byproducts of enzymatic hydrolysis residue (EHR) indicated their bioenergy potential as the clean fuels.

2. The thermogravimetric (TG) analysis showed that the pyrolysis of EHR mainly occurred in the range of $370{ }^{\circ} \mathrm{C}$ to $620^{\circ} \mathrm{C}$, and the weight loss rate was the fastest at $355{ }^{\circ} \mathrm{C}$ when evaluating alkaline hydrogen peroxide-EHR (AHP-EHR) and bisulfiteEHR (BSF-EHR). The IR analysis indicated that the main volatile products of EHR were $\mathrm{CO}_{2}, \mathrm{CO}$, and light hydrocarbon.

3. The kinetic parameters of pyrolysis were calculated using the Coats-Redfern method to determine the highest thermal decomposition rate in the second stage. The activation energy of AHP-EHR pyrolysis was calculated using the Coats-Redfern method was different from that of BSF-EHR, which could be attributed to the higher lignin content and slightly lower hemicellulose content of AHP-EHR than BSF-EHR.

4. Moreover, a large number of pyrolysis products were identified by pyrolysis gas chromatography/mass spectrometry (Py-GC/MS) analysis, including phenols, furans, carbonyl compounds, and other oxides. All results confirmed that EHR can be turned into a solid fuel and served as an advantageous feedstock for thermochemical application.

\section{ACKNOWLEDGMENTS}

The financial support from international cooperation program of Qilu University of Technology, Grant No. QLUTGJHZ2018012. The project was also supported by the foundation (Nos. ZZ20190308 and ZZ20190304) of State Key Laboratory of Biobased Material and Green Papermaking, Qilu University of Technology, Shandong Academy of Sciences.

\section{REFERENCES CITED}

Akalın, M. K., and Karagöz, S. (2014). "Analytical pyrolysis of biomass using gas chromatography coupled to mass spectrometry," TrAC Trends Anal. Chem. 61, 11-16. DOI: $10.1016 /$ j.trac.2014.06.006

Amaral, H. R., Cipriano, D. F., Santos, M. S., Schettino, Jr., M. A., Ferreti, J. V. T., Meirelles, C. S., Pereira, V. S., Cunha, A. G., Emmerich, F. G., and Freitas, J. C. C. (2019). "Production of high-purity cellulose, cellulose acetate and cellulose-silica composite from babassu coconut shells," Carbohyd. Polym. 210, 127-134. DOI: 10.1016/j.carbpol.2019.01.061 
Barr, M. R., Volpe, R., and Kandiyoti, R. (2019). "Influence of reactor design on product distributions from biomass pyrolysis," ACS Sustain. Chem. Eng. 7(16), 13734-13745. DOI: 10.1021/acssuschemeng.9b01368

Cai, J., Xu, D., Dong, Z., Yu, X., Yang, Y., Banks, S. W., and Bridgwater, A. V. (2018). "Processing thermogravimetric analysis data for isoconversional kinetic analysis of lignocellulosic biomass pyrolysis: Case study of corn stalk," Renew. Sust. Energ. Rev. 82(Part 3), 2705-2715. DOI: 10.1016/j.rser.2017.09.113

Cao, J., Xiao, G., Xu, X., Shen, D., and Jin, B. (2013). "Study on carbonization of lignin by TG-FTIR and high-temperature carbonization reactor," Fuel Process. Technol. 106, 41-47. DOI: 10.1016/j.fuproc.2012.06.016

Chandra, R. P., Gourlay, K., Kim, C. S., and Saddler, J. K. (2015). "Enhancing hemicellulose recovery and the enzymatic hydrolysis of cellulose by adding lignosulfonates during the two-stage steam pretreatment of poplar," ACS Sustain. Chem. Eng. 3(5), 986-991. DOI: 10.1021/acssuschemeng.5b00124

Chen, D., Liu, D., Zhang, H., Chen, Y., and Li, Q. (2015). "Bamboo pyrolysis using TGFTIR and a lab-scale reactor: Analysis of pyrolysis behavior, product properties, and carbon and energy yields," Fuel 148, 79-86. DOI: 10.1016/j.fuel.2015.01.092

Chen, X., Zhai, R., Shi, K., Yuan, Y., Dale, B. E., Gao, Z., and Jin, M. (2018). "Mixing alkali pretreated and acid pretreated biomass for cellulosic ethanol production featuring reduced chemical use and decreased inhibitory effect," Ind. Crop. Prod. 124, 719-725. DOI: 10.1016/j.indcrop.2018.08.056

Chen, H., Xie, Y., Chen, W., Xia, M., Li, K., Chen, Z., Chen, Y., and Yang, H. (2019). "Investigation on co-pyrolysis of lignocellulosic biomass and amino acids using TGFTIR and Py-GC/MS," Energ. Convers. Manage. 196, 320-329. DOI: 10.1016/j.enconman.2019.06.010

Deng, D., Duan, X. X., Lu, J. J., Qin, Y., and Wang, C. (2019). "Electrogenerated alkaline hydrogen peroxide for rice straw pretreatment to enhance enzymatic hydrolysis," Bioresource Technol. 292, Article ID 122077. DOI: 10.1016/j.biortech.2019.122077

Dhyani, V., and Bhaskar, T. (2018). "A comprehensive review on the pyrolysis of lignocellulosic biomass," Renew. Energy 129(Part B), 695-716. DOI: 10.1016/j.renene.2017.04.035

Ferreira, E. N., Arruda, T. B. M. G., Rodrigues, F. E. A., Arruda, D. T. D., Júnior, J. H. S., Porto, D. L., and Ricardo, N. M. P. S. (2019). "Investigation of the thermal degradation of the biolubricant through TG-FTIR and characterization of the biodiesel-Pequi (Caryocar brasiliensis) as energetic raw material," Fuel 245, 398405. DOI: 10.1016/j.fuel.2019.02.006

Gil, M. V., Casal, D., Pevida, C., Pis, J. J., and Rubiera, F. (2010). “Thermal behaviour and kinetics of coal/biomass blends during co-combustion," Bioresource Technol. 101(14), 5601-5608. DOI: 10.1016/j.biortech.2010.02.008

Gu, X., Liu, C., Jiang, X., Ma, X., Li, L., Cheng, K., and Li, Z. (2014). “Thermal behavior and kinetics of the pyrolysis of the raw/steam exploded poplar wood sawdust," J. Anal. Appl. Pyrol. 106, 177-186. DOI: 10.1016/j.jaap.2014.01.018

Gu, X., Ma, X., Li, L., Liu, C., Cheng, K., and Li, Z. (2013). "Pyrolysis of poplar wood sawdust by TG-FTIR and Py-GC/MS," J. Anal. Appl. Pyrol. 102, 16-23. DOI: 10.1016/j.jaap.2013.04.009

Ho, M. C., Ong, V. Z., and Wu, T. Y. (2019). "Potential use of alkaline hydrogen peroxide in lignocellulosic biomass pretreatment and valorization-A review," Renew. Sust. Energ. Rev. 112, 75-86. DOI: 10.1016/j.rser.2019.04.082 
Huang, H., Liu, J. Y., Liu, H., Evrendilek, F., and Buyukada, M. (2020). "Pyrolysis of water hyacinth biomass parts: Bioenergy, gas emissions, and byproducts using TGFTIR and Py-GC/MS analyses," Energ. Convers. Manage. 207, Article ID 112552. DOI: $10.1016 /$ j.enconman.2020.112552

Huang, Y. F., Kuan, W. H., Chiueh, P. T., and Lo, S. L. (2011). "Pyrolysis of biomass by thermal analysis-mass spectrometry (TA-MS)," Bioresource Technol. 102(3), 35273534. DOI: 10.1016/j.biortech.2010.11.049

Jayaraman, K., Kok, M. V., and Gokalp, I. (2017). "Thermogravimetric and mass spectrometric (TG-MS) analysis and kinetics of coal-biomass blends," Renew. Energy 101, 293-300. DOI: 10.1016/j.renene.2016.08.072

Jin, M., da Costa Sousa, L., Schwartz, C., He, Y., Sarks, C., Gunawan, C., Balan, V., and Dale, B. E. (2016). "Toward lower cost cellulosic biofuel production using ammonia based pretreatment technologies," Green Chem. 18(4), 957-966. DOI: $10.1039 / \mathrm{c} 5 \mathrm{gc0} 2433 \mathrm{a}$

Kan, T., Strezov, V., and Evans, T. J. (2016). "Lignocellulosic biomass pyrolysis: A review of product properties and effects of pyrolysis parameters," Renew. Sust. Energ. Rev. 57, 1126-1140. DOI: 10.1016/j.rser.2015.12.185

Kan, X., Zhang, J., Tong, Y. W., and Wang, C. (2018). “Overall evaluation of microwaveassisted alkali pretreatment for enhancement of biomethane production from brewers' spent grain," Energ. Convers. Manage. 158, 315-326. DOI:

10.1016/j.enconman.2017.12.088

Kruse, A., Funke, A., and Titirici, M. M. (2013). "Hydrothermal conversion of biomass to fuels and energetic materials," Curr. Opin. Chem. Biol. 17(3), 515-521. DOI: 10.1016/j.cbpa.2013.05.004

Li, B., Lv, W., Zhang, Q., Wang, T., and Ma, L. (2014). "Pyrolysis and catalytic pyrolysis of industrial lignins by TG-FTIR: Kinetics and products," J. Anal. Appl. Pyrol. 108, 295-300. DOI: 10.1016/j.jaap.2014.04.002

Li, F., Srivatsa, S. C., Batchelor, W., and Bhattacharya, S. (2017a). "A study on growth and pyrolysis characteristics of microalgae using thermogravimetric analysis-infrared spectroscopy and synchrotron Fourier transform infrared spectroscopy," Bioresource Technol. 229, 1-10. DOI: 10.1016/j.biortech.2017.01.005

Li, J., Lu, M., Guo, X., Zhang, H., Li, Y., and Han, L. (2018). "Insights into the improvement of alkaline hydrogen peroxide (AHP) pretreatment on the enzymatic hydrolysis of corn stover: Chemical and microstructural analyses," Bioresource Technol. 265, 1-7. DOI: 10.1016/j.biortech.2018.05.082

Li, J., Tian, Y., Zong, P., Qiao, Y., and Qin, S. (2020). “Thermal cracking behavior, products distribution and char/steam gasification kinetics of seawater Spirulina by TG-FTIR and Py-GC/MS," Renew. Energy 145, 1761-1771. DOI: 10.1016/j.renene.2019.07.096

Li, K., Zhu, C., Zhang, L., and Zhu, X. F. (2016). "Study on pyrolysis characteristics of lignocellulosic biomass impregnated with ammonia source," Bioresource Technol. 209, 142-147. DOI: 10.1016/j.biortech.2016.02.136

Li, M. F., Yu, P., Li, S. X., Wu, X., Xiao, X., and Bian, J. (2017b). “Sequential two-step fractionation of lignocellulose with formic acid organosolv followed by alkaline hydrogen peroxide under mild conditions to prepare easily saccharified cellulose and value-added lignin," Energ. Convers. Manage. 148, 1426-1437. DOI: 10.1016/j.enconman.2017.07.008

Li, X., Xu, Z., Yu, J., Huang, H., and Jin, M. (2019). “In situ pretreatment during 
distillation improves corn fiber conversion and ethanol yield in the dry mill process," Green Chem. 21(5), 1080-1090. DOI: 10.1039/C8GC03447H

Liang, F., Wang, R., Xiang, H. Z., Yang, X. M., Zhang, T., Hu, W., Mi, B., and Liu, Z. (2018). "Investigating pyrolysis characteristics of moso bamboo through TG-FTIR and Py-GC/MS," Bioresource Technol. 256, 53-60. DOI:

10.1016/j.biortech.2018.01.140

Liu, T., Williams, D. L., Pattathil, S., Li M., Hahn, M. G., and Hodge, D. B. (2014). "Coupling alkaline pre-extraction with alkaline-oxidative post-treatment of corn stover to enhance enzymatic hydrolysis and fermentability," Biotechnol. Biofuels 7(1), 48-59. DOI: 10.1186/1754-6834-7-48

Liu, T., Yang, L., Liu, B., and Tan, L. (2019). "Hydroxycinnamic acids release during bioconversion of corn stover and their effects on lignocellulolytic enzymes," Bioresource Technol. 294, Article ID 122116. DOI: 10.1016/j.biortech.2019.122116

Long, J., Zhang, Q., Wang, T., Zhang, X., Xu, Y., and Ma, L. (2014). “An efficient and economical process for lignin depolymerization in biomass-derived solvent tetrahydrofuran," Bioresource Technol. 154, 10-17. DOI: 10.1016/j.biortech.2013.12.020

Luo, X., Gleisner, R., Tian, S., Negron, J., Zhu, W., Horn, E., Pan, X. J., and Zhu, J. Y. (2010). "Evaluation of mountain beetle-infested lodgepole pine for cellulosic ethanol production by sulfite pretreatment to overcome recalcitrance of lignocellulose," Ind. Eng. Chem. Res. 49(17), 8258-8266. DOI: 10.1021/ie1003202

Ming, X., Xu, F., Jiang, Y., Zong, P., Wang, B., Li, J., Qiao, Y., and Tian, Y. (2020). "Thermal degradation of food waste by TG-FTIR and Py-GC/MS: Pyrolysis behaviors, products, kinetic and thermodynamic analysis," J. Clean. Prod. 244, Article ID 118713. DOI: 10.1016/j.jclepro.2019.118713

Mishra, R. K., and Mohanty, K. (2018). "Pyrolysis kinetics and thermal behavior of waste sawdust biomass using thermogravimetric analysis," Bioresource Technol. 251, 6374. DOI: 10.1016/j.biortech.2017.12.029

Papa, G., Feldman, T., Sale, K. L., Adani, F., Singh, S., and Simmons, B. A. (2017). "Parametric study for the optimization of ionic liquid pretreatment of corn stover," Bioresource Technol. 241, 627-637. DOI: 10.1016/j.biortech.2017.05.167

Ren, Q., Zhao, C., Wu, X., Liang, C., Chen, X., Shen, J., Tang, G., and Wang, Z. (2009). "TG-FTIR study on co-pyrolysis of municipal solid waste with biomass," Bioresource Technol. 100(17), 4054-4057. DOI: 10.1016/j.biortech.2009.03.038

Sahoo, D., Ummalyma, S. B., Okram, A. K., Pandey, A., Sankar, M., and Sukumaran, R. K. (2018). "Effect of dilute acid pretreatment of wild rice grass (Zizania latifolia) from Loktak Lake for enzymatic hydrolysis," Bioresource Technol. 253, 252-255. DOI: 10.1016/j.biortech.2018.01.048

Sluiter, A., Hames, B., Ruiz, R., Scarlata, C., Sluiter, J., Templeton, D., and Crocker, D. (2008). Determination of Structural Carbohydrates and Lignin in Biomass (NREL/TP-510-42618), National Renewable Energy Laboratory, Golden, CO, USA.

Soccol, C. R., Faraco, V., Karp, S. G., Vandenberghe, L. P. S., Thomaz-Soccol, V., Woiciechowski, A. L., and Pandey, A. (2019). "Lignocellulosic bioethanol: Current status and future perspectives," in: Biofuels: Alternative Feedstocks and Conversion Processes for the Production of Liquid and Gaseous Biofuels, Academic Press, Cambridge, MA, USA, pp. 331-354.

Tan, L., Sun, W., Li, X., Zhao, J., Qu, Y., Choo, Y. M., and Loh, S. K. (2015). "Bisulfite pretreatment changes the structure and properties of oil palm empty fruit bunch to 
improve enzymatic hydrolysis and bioethanol production," Biotechnol. J. 10(6), 915925. DOI: 10.1002/biot.201400733

Tan, L., Wang, M., Li, X., Li, H., Zhao, J., Qu, Y., Choo, Y. M., and Loh, S. K. (2016). "Fractionation of oil palm empty fruit bunch by bisulfite pretreatment for the production of bioethanol and high value products," Bioresource Technol. 200, 572578. DOI: 10.1016/j.biortech.2015.10.079

Tan, L., Yu, Y., Li, X., Zhao, J., Qu, Y., Choo, Y. M., and Loh, S. K. (2013). "Pretreatment of empty fruit bunch from oil palm for fuel ethanol production and proposed biorefinery process," Bioresource Technol. 135, 275-282. DOI: 10.1016/j.biortech.2012.10.134

Tripathi, M., Sahu, J. N., and Ganesan, P. (2016). "Effect of process parameters on production of biochar from biomass waste through pyrolysis: A review," Renew. Sust. Energ. Rev. 55, 467-481. DOI: 10.1016/j.rser.2015.10.122

Wang, S., Lin, H., Ru, B., Sun, W., Wang, Y., and Luo, Z. (2014). "Comparison of the pyrolysis behavior of pyrolytic lignin and milled wood lignin by using TG-FTIR analysis," J. Anal. Appl. Pyrol. 108, 78-85. DOI: 10.1016/j.jaap.2014.05.014

Wang, Z. J., Lan, T. Q., and Zhu, J. Y. (2013). "Lignosulfonate and elevated pH can enhance enzymatic saccharification of lignocelluloses," Biotechnol. Biofuels 6(1), 919. DOI: $10.1186 / 1754-6834-6-9$

Wu, X., Ba, Y., Wang, X., Niu, M., and Fang, K. (2018). "Evolved gas analysis and slow pyrolysis mechanism of bamboo by thermogravimetric analysis, Fourier transform infrared spectroscopy and gas chromatography-mass spectrometry," Bioresource Technol. 266, 407-412. DOI: 10.1016/j.biortech.2018.07.005

Yuan, Z., Wen, Y., and Kapu, N. S. (2018). "Ethanol production from bamboo using mild alkaline pre-extraction followed by alkaline hydrogen peroxide pretreatment," Bioresource Technol. 247, 242-249. DOI: 10.1016/j.biortech.2017.09.080

Zhang, B., Yang, D., Wang, H., Qian, Y., Huang, J., Yu, L., and Qiu, X. (2018). "Activation of enzymatic hydrolysis lignin by $\mathrm{NaOH} /$ urea aqueous solution for enhancing its sulfomethylation reactivity," ACS Sustain. Chem. Eng. 7(1), 1120-1128. DOI: 10.1021/acssuschemeng.8b04781

Zhang, H., Huang, S., Wei, W., and Zhang, J., and Xie, J. (2019). "Investigation of alkaline hydrogen peroxide pretreatment and Tween 80 to enhance enzymatic hydrolysis of sugarcane bagasse," Biotechnol. Biofuels 12(1), 107-115. DOI: $10.1186 / \mathrm{s} 13068-019-1454-3$

Article submitted: November 26, 2020; Peer review completed: January 31, 2021; Revised version received and accepted: February 14, 2021; Published: February 18, 2021. DOI: 10.15376/biores.16.2.2626-2643 